\title{
Pengaruh Penggilingan Terhadap Penetrasi cream Asiklovir
}

\author{
(The Effect Of Milling Process To Penetration of Acyclovir Cream)
}

\author{
Deni Noviza*, dan Rara Monisah
}

Fakultas Farmasi, Universitas Andalas

\begin{abstract}
This study aimed to observe the effect of milling on acyclovir on the penetration of acyclovir cream. Acyclovir milling used ball mill with variation of time 1 hour, 3 hour and 6 hours. Furthermore, acyclovir formulated into cream and evaluated for its physicochemical properties and penetration. Base cream without active substances and acyclovir cream on the market used as a comparison. The release test was carried out using Franz horizontal type diffusion cells and penetrated acyclovir measured using a UV-Vis spectrophotometer with a maximum absorption wavelength of $254 \mathrm{~nm}$. The results showed that the cream preparations were homogeneous, with range of pH between 7-7.5, M / A cream type, easy to wash and non-irritating. The 1 and 3-hour milling process causes a decrease in particle size which increases the amount of penetrated acyclovir, meanwhile 6-hour milling causes the formation of aggregates with a larger particle size, causing the amount of penetrated acyclovir to be lower than acyclovir cream without grinding. The grinding process of acyclovir did not influenced the properties of the cream but the longer of milling process causes a decrease in the amount of the penetrated acyclovir
\end{abstract}

Keywords: Acyclovir, milling, cream, sel diffusion franz, penetration.

ABSTRAK: Tujuan dari penelitian ini adalah untuk melihat pengaruh penggilingan pada asiklovir terhadap sifat fisikokimia dan penetrasi dari cream asiklovir. Penggilingan asiklovir menggunakan alat ball mill dengan variasi lama penggilingan 1, 3 dan 6 jam. Asiklovir kemudian diformulasikan menjadi cream dan dilakukan evaluasi sifat fisikokimia dan penetrasinya. Sebagai pembanding digunakan basis cream tanpa zat aktif dan cream asiklovir yang sudah beredar. Uji pelepasan dilakukan dengan menggunakan sel difusi Franz jenis horizontal dan kadar asiklovir yang terpenetrasi diukur menggunakan Spektrofotometer UV-Vis dengan panjang gelombang serapan maksimum $254 \mathrm{~nm}$. Hasil penelitian menunjukkan bahwa sediaan cream yang dihasilkan homogen, dengan $\mathrm{pH}$ antara 7-7,5, type cream M/A, Sediaan cream mudah tercuci dan tidak menyebabkan iritasi. Proses penggilingan 1 dan 3 jam menyebabkan terjadinya penurunan ukuran partikel sehingga meningkatkan jumlah asiklovir yang terpenetrasi, sedangkan penggilingan 6 jam menyebabkan terbentuknya agregat dengan ukuran partikel lebih besar, sehingga menyebabkan jumlah asiklovir yang terpenetrasi lebih rendah dibandingkan cream asiklovir tanpa penggilingan. Proses penggilingan terhadap asiklovir tidak mempengaruhi sifat dari cream tapi semakin lama proses penggilingan menyebabkan penurunan jumlah zat yang terpenetrasi.

Kata kunci: Asiklovir, penggilingan, cream, sel difusi franz, penetrasi.

\section{Pendahuluan}

Asiklovir merupakan obat antivirus yang digunakan secara luas untuk pengobatan herpes simplex. Asiklovir digunakan dalam pengobatan infeksi virus herpes pada genital, kulit, dan membran mukosa, serta mengobati gejala cacar air [1]. Asiklovir bersifat sukar larut dalam air [2].

Herpes Simpleks merupakan infeksi virus yang ditandai dengan episode berulang dari lepuhan-lepuhan kecil di kulit atau selaput lendir, yang berisi cairan dan terasa nyeri. Herpes simpleks menyebabkan timbulnya erupsi pada kulit atau selaput lendir. Erupsi pada kulit ini kebanyakan disebabkan oleh herpes simpelk tipe 1
(HSV-1). $80 \%$ dari penderita akan tetap mengandung virus dan sekitar $40 \%$ akan mendapatkan infeksi berulang [3]. Sekitar $1 \%$ penderita akan membawa virus selama bulanan. Infeksi virus ini akan terjadi selama 4 sampai 10 hari dan bisa berlangsung sampai 30 hari pada pasien dengan daya tahan tubuh lemah, dimana lepuhan kulit akan berubah menjadi nekrosis [4]. Dari hasil penelitian yang dilakukan secara acak dan doubleblind menyatakan bahwa pemberian anti virus seperti asiklovir dengan rute pemberian topikal efektif untuk mempersingkat durasi lepuhan dan mengurangi rasa sakit_5].

Untuk mendapatkan hasil terbaik, obat anti virus harus mencapai konsentrasi terapi dalam
Access this article

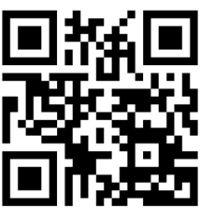


cell basal epidermis, dimana sel ini merupakan pintu gerbang virus bisa disebarkan [6,7]. Konsekwensinya penentrasi obat pada stratum corneum kulit merupakan faktor kritis keberhasilan terapi dengan menggunakan sediaan topikal [3,8].

Ada beberapa cara yang bisa digunakan untuk meningkatkan penetrasi obat melalui stratum corneum kulit, salah satunya dengan memperkecil ukuran partikel sehingga permeabilitas obat lebih baik [8].

Penelitian ini bertujuan untuk mengetahui pengaruh waktu penggilingan terhadap sifat fisiko kimia dan daya penetrasi cream asiklovir. Selain itu juga dilakukan perbandingan sifat fisiko kimia dan daya penetrasi cream asiklovir hasil penggilingan dengan cream asiklovir yang sudah beredar.

\section{Metode Penelitian}

Bahan

Asiklovir (PT. Sampharindo, Jakarta, Indonesia), Paraffin Liquidum (Bratachem), Setil Alkohol (Bratachem), Trietanolamin (Bratchem), Asam stearate (Bratachem), Gliserin (Bratachem).

Penggilingan Asiklovir

Penggilingan asiklovir dilakukan dengan menggunakan alat Ball Mill selama 1 jam, 3 jam, dan 6 jam dengan kecepatan $100 \mathrm{rpm}$.

\section{Pembuatan Sediaan Cream Asiklovir}

Formula cream yang digunakan adalah sebagi berikut:

Cara Pembuatan Cream

1. Fase minyak (asam stearate, setil alcohol dan paraffin liquidum) dilebur didalam oven suhu 70oC, selama 15 menit

2. Fase air (TEA dan gliserin) dilarutkan dalam air suhu $70 \circ \mathrm{C}$.

3. Fase minyak dan air dicampurkan dalam kondisi panas sampai terbentuk masa cream

4. Asiklovir dicampurkan ke masa basis cream setelah suhu basisnya dingin.

\section{Evaluasi Cream Asiklovir}

A. Pemeriksaan Organoleptis

Meliputi pemeriksaan bentuk, bau dan warna yang dilakukan secara visual.

B. Pemeriksaan Homogenitas

0,1 g sediaan dioleskan pada sekeping kaca yang transparan, sediaan harus menunjukkan susunan yang homogen dan tidak boleh terlihat adanya bintik-bintik partikel.

C. Pemeriksaan $\mathrm{pH}$

Pemeriksaan dilakukan dengan menggunakan alat pH meter. Pertama alat dikalibrasi dengan menggunakan larutan dapar $\mathrm{pH}$ 4, $\mathrm{pH} 7$ dan $\mathrm{pH}$ 9. Setelah alat menunjukkan $\mathrm{pH}$ sesuai dengan larutan standar, maka dilakukan pengujian dengan terhadap sediaan dengan cara mencelupkan katoda ke dalam sediaan, berapa angka yang tertera pada alat merupakan $\mathrm{pH}$ sediaan.

D. Pemeriksaan Tipe Cream

Selapis tipis cream di oleskan pada kaca objek kemudian ditetesi dengan larutan metilen biru. Untuk tipe M/A akan terlihat larutan metilen biru mewarnai fase air sehingga mewarnai seluruh cream.

E. Pemeriksaan Ukuran Partikel [9]

Pengukuran dilakukan dengan memakai alat mikroskop yang dilengkapi dengan alat Optilab viewer dan duhubungkan ke laptop. Caranya adalah sebagai berikut : Ditimbang 0,1 gram cream, kemudian diencerkan dengan air suling sampai $1 \mathrm{~mL}$, diambil sedikit hasil pengenceran tersebut diteteskan pada kaca objek, lalu dilakukan pegukuran partikel sampai dengan 1000 partikel.

F. Pemeriksaan Daya Tercuci [10]

Pemeriksaan daya tercuci dalam sediaan dilakukan dengan cara 1 gram sediaan cream dioleskan pada telapak tangan manusia lalu dicuci dengan sejumlah air tertentu, jika noda-noda yang berupa minyak tidak terdapat lagi berarti sediaan telah tercuci, dicatat volume air yang terpakai.

G. Uji Daya Menyebar [11]

Sediaan sebanyak 0,5 gram diletakkan dengan hati-hati di atas kertas grafik yang dilapisi dengan kaca transparan, dibiarkan sesaat (15 detik) dan dihitung luas daerah yang diberikan oleh sediaan kemudian ditutupi lagi dengan plastik transparan diberi beban tertentu $(1,3,5$, 7, 9, 11, 13, 15 gram) dan dibiarkan selama 60 detik, lalu dihitung pertambahan luas yang diberikan oleh sediaan.

H. Uji Iritasi

Uji iritasi menggunakan panelis sebanyak 5 orang. Sediaan cream di tempel pada lengan bagian dalam panelis seluas $2 \mathrm{~cm}$, kemudian ditutup rapat. Biarkan selama 24 jam. Amati terjadinya reaksi iritasi pada panelis.

\section{Uji Daya Penetrasi}

a. Penyediaan kulit mencit sebagai membran penetrasi

Mencit yang telah dibunuh diambil seluruh kulitnya kecuali bagian kepala dan kaki dengan bantuan gunting bedah. Bagian kulit yang telah dipotong dibersihkan dari lemak-lemak yang menempel, bulu-bulunya digunting 
kemudian dicukur dengan hati-hati sampai kulit mencit tersebut bersih dari bulu-bulunya, setelah itu kulit dibersihkan dengan menggunakan air suling dan dibilas dengan larutan $\mathrm{NaCl}$ 0,9\% untuk melepaskan sisa jaringan yang masih melekat.

\section{b.Uji daya penetrasi menggunakan sel difusi Franz}

Kompartemen cairan penerima pada alat sel difusi Franz diisi dengan larutan $\mathrm{NaCl} 0,9 \%$. Sediaan cream ditimbang sebanyak $250 \mathrm{mg}$, lalu dioleskan secara merata pada kulit mencit yang diletakkan pada alat sel difusi Franz. Setelah itu bagian tepi dari daerah pengolesan tadi ditutup dengan tutup gelas kaca yang dilengkapi dengan penjepit kemudian stirrer dimasukkan kedalam sel difusi Franz. Sel Difusi Franz kemudian diletakkan pada bejana kaca berisi air yang dilengkapi dengan termostat dan termometer untuk pengaturan suhu. Suhu air pada bejana kaca diatur pada $37 \mathrm{oC} \pm 1{ }^{\circ} \mathrm{C}$. Magnetik stirrer dihidupkan dan diatur skala untuk perputaran $120 \mathrm{rpm}$, suhu dijaga $\pm 37 \mathrm{oC}$. Pengambilan cuplikan $(5 \mathrm{ml})$ dilakukan berturut-turut pada 5, 10, 20, 30, 45, 60, 75, 90, 105, 120, 135, 150, 165, 180, 195, 210, 225, 240 menit; setip cuplikan yang diambil diganti dengan larutan $\mathrm{NaCl}$ 0,9\% dengan volume dan suhu yang sama. Penentuan kadar dari sampel dilakukan dengan spektrofotometer UV-Visible

\section{Hasil dan Diskusi}

Ukuran partikel merupakan salah satu faktor yang mempengaruhi penetrasi zat aktif pada sediaan topical. Banyak metode yang bisa digunakan untuk memperkecil ukuran partikel, salah satunya dengan penggilingan [12]. Pada penelitian ini penggilingan menggunakan alat ball mill dengan variasi waktu penggilingan 1, 3 dan 6 jam. Hasil penggilingan ini kemudian diformulasikan menjadi bentuk sediaan cream dengan menggunakan cream dengan asiklovir tanpa perlakuan, basis cream dan cream asiklovir yang sudah beredar sebagai pembanding.

Evaluasi pertama yang dilakukan terhadap sediaan cream adalah dengan melihat organoleptis. Sediaan cream semua formula memiliki bentuk setangah padat, berwarna putih dan tidak berbau.

Uji homogenitas dan penentuan tipe cream dilakukan dengan menggunakan kaca objek yang diolesin sediaan cream. Sediaan akan dikatakan homogen kalau tidak ada terbentuk partkel kasar pada sediaan. Kemudian pada cream ditetesi metilen biru. Didapatkan bahwa seluruh bagian cream berwarna biru. Hasil pengujian ini memunjukkan bahwa semua formula cream homogen dan tipe cream nya $\mathrm{M} / \mathrm{A}$.
Pengujian pH dilakukan selama 5 minggu. $\mathrm{pH}$ sediaan cream mengalami sedikit penurunan pada suhu 25oC, yang mengindikasikan bahwa sediaannya stabil. Walaupun terjadi penurunan $\mathrm{pH}$ tapi $\mathrm{pH}$ sediaan masih dalam rentang 7 - 7,5. Hal ini menunjukkan bahwa stabilitas maksimum dari sediaan akan berlangsung dalam jangka waktu lama kalau sediaan disimpan pada suhu 25oC [13]

Pada penggilingan asiklovir terjadi proses agregasi dan aglomerasi partikel-partikel halus akibat meningkatnya energi permukaan dan gaya Van der Waals antara molekulmolekul membentuk aglomerat. Hal ini didukung dengan hasil distribusi ukuran partikel sampel yang menunjukan tingginya frekuensi partikel berdiameter halus dan adanya partikel yang berukuran besar. Aglomerat ini dapat dilihat dari hasil SEM penggilingan asiklovir [12]. Semakin lama proses penggilingan maka semakin banyak dan besar aglomerat yang terbentuk. Hal ini disebabkan permukaan partikel aglomerat yang terbentuk dapat menyerap udara dan sifat pembasahan dalam air yang buruk. Padahal pembasahan serbuk merupakan tahap awal untuk melarut. Sehingga serbuk mengapung pada medium disolusi dan menyebabkan penurunan laju disolusi [14].

Hasil pemeriksaan daya tercuci menunjukkan bahwa cream asiklovir dapat tercuci dengan baik menggunakan air sebanyak $20 \mathrm{ml}$. Hal ini disebabkan karena tipe cream $\mathrm{M} / \mathrm{A}$ sehingga mudah dicuci.

Pemeriksaan daya menyebar bertujuan untuk mengetahui kemampuan menyebar sediaan diatas permukaan kulit saat pemakaian. Pemeriksaan ini dilakukan secara manual dengan prinsip menghitung pertambahan luas yang diberikan oleh sediaan dalam waktu tertentu. Dari hasil pemeriksaan daya menyebar didapatkan bahwa sediaan cream mengalami perubahan daya menyebar yang relative sama yaitu sekitar $5 \mathrm{~cm} 2$, kalau dibandingkan dengan sediaan yang beredar (F6) didapatkan bahwa sediaan beredar lebih besar daya menyebarnya dibandingkan sediaan cream asiklovir yang digiling.

Uji iritasi dilakukan pada manusia sehat yang berumur 20-30 tahun. Hasil pemeriksaan menunjukkan bahwa sediaan cream semua formula tidak menyebabkan reaksi iritasi.

Penentuan permeabilitas In Vitro senyawa melewati kulit tipis hewan berguna untuk pengevaluasi difusi passive dari molekul ke dan melewati kulit masuk ke wadah penampung [3].

Uji daya penetrasi cream asiklovir menggunakan sel difusi Franz tipe vertical. Prinsip sel difusi Franz adalah dengan meletakkan membrane semi permeable diantara wadah donor dan reseptor $[15,16]$. Alat ini dilengkapi 
dengan pengaduk magnetik dalam wadah donor yang bertujuan untuk menghomogenkan distribusi asiklovir yang akan berpentrasi melalui kulit. Proses penetrasi zat aktif untuk melewati membran semi permeabel (kulit mencit) dan terdistribusi di dalam cairan penerima terjadi secara difusi pasif.

Dari hasil uji penetrasi sediaan cream asiklovir menunjukkan bahwa semakin lama waktu penggilingan maka semakin banyak asiklovir yang terpenetrasi, tapi pada F4 (yang mengandung asiklovir dengan penggilingan 6 jam) terjadi penurunan jumlah terpentrasi, malah kadarnya lebih kecil dari asiklovir tanpa perlakuan. Hal ini terjadi karena semakin lama proses penggilingan maka semakin besar kemungkinan terbentuknya agregat, yang akhirnya akan mempengaruhi penetrasi obat melalui kulit. Hal ini didukung oleh daya hasil penentuan distribusi ukuran partikel.

Peristiwa terjadinya penetrasi zat aktif yang berada dalam pembawa seperti cream sangat dipengaruhi oleh banyak factor, antara lain kelarutan zat. Semakin mudah larut zat tersebut, maka semakin bagus penetrasi nya melewati kulit.

Tabel 1. Formula Cream Asiklovir

\begin{tabular}{|c|c|c|c|c|c|c|}
\hline \multirow{2}{*}{ Bahan } & \multicolumn{6}{|c|}{ Formula } \\
\hline & F1 & F2 & F3 & F4 & F5 & F6 \\
\hline Asiklovir 5\% & V & - & - & - & - & - \\
\hline Asiklovir penggilingan 1 jam 5\% & - & V & - & - & - & - \\
\hline Asiklovir penggilingan 3 jam 5\% & - & - & $v$ & - & - & - \\
\hline Asiklovir penggilingan 6 jam 5\% & - & - & - & v & - & - \\
\hline Asiklovir cream yang beredar & - & - & - & - & $\mathrm{v}$ & - \\
\hline Asam Stearat 3,5\% & $v$ & V & $v$ & $v$ & - & $v$ \\
\hline Setil Alkohol $1 \%$ & $\mathrm{v}$ & $\mathrm{v}$ & $v$ & $v$ & - & $\mathrm{v}$ \\
\hline Paraffin Liquid $10 \%$ & $v$ & V & $v$ & $v$ & - & $v$ \\
\hline Gliserin $5 \%$ & V & V & $v$ & $v$ & - & v \\
\hline Trietanolamin $1 \%$ & V & V & $v$ & $v$ & - & v \\
\hline Aquadest ad $100 \%$ & $\mathrm{v}$ & $\mathrm{v}$ & $\mathrm{v}$ & $\mathrm{v}$ & - & $\mathrm{v}$ \\
\hline
\end{tabular}

Keterangan:

F1 = Cream Asiklovir tanpa perlakuan

F2 = Cream asiklovir dengan penggerusan selama $1 \mathrm{jam}$

F3 = Cream Asiklovir dengan penggerusan selama 3 jam

F4 = Cream Asiklovir dengan penggerusan selama 6 jam

F5 $=$ Basis Cream

F6 = Cream Asiklovir yang beredar

Tabel 2. Hasil Evaluasi Cream Asiklovir

\begin{tabular}{|cccccccc|}
\hline No & Pemeriksaan & F1 & F2 & F3 & F4 & F5 & F6 \\
\hline 1. & Bentuk & Setengah & Setengah & Setengah & Setengah & Setengah Padat & Setengah \\
Padat & Padat & Padat & Padat & Putih & Putih \\
2. & Warna & Puth & Puth & Putih & Puth & Tidak Berbau \\
3. & Bau & Tidak Berbau & Tidak Berbau & Tidak Berbau & Tidak Berbau & Tidak Berbau & Homogen \\
4. & Homogenitas & Homogen & Homogen & Homogen & Homogen & Homogen & M/A \\
5. & Tipe Cream & M/A & M/A & M/A & M/A & M/A & \\
\hline
\end{tabular}


Tabel 3. Hasil Pemeriksaan pH Krim Asiklovir

\begin{tabular}{|ccccccc|}
\hline Minggu ke & F1 & F2 & F3 & F4 & F5 & F6 \\
\hline 1 & 7,5 & 7,3 & 7,2 & 7,2 & 7,4 & 6,9 \\
2 & 7,5 & 7,3 & 7,1 & 7,15 & 7,3 & 6,8 \\
3 & 7,2 & 7,2 & 7,1 & 7,1 & 7,1 & 7,05 \\
4 & 7,1 & 7,05 & 7 & 7,05 & 7 & 7 \\
5 & 7,1 & 7 & 7 & 7 & 7 & 7 \\
\hline
\end{tabular}

Tabel 4. Hasil Pemeriksaan Daya Tercuci

\begin{tabular}{|c|c|c|c|c|c|c|c|}
\hline No & Jumlah Air & F1 & F2 & F3 & F4 & F5 & F6 \\
\hline 1 & $10 \mathrm{ml}$ & - & - & - & - & - & - \\
\hline 2 & $20 \mathrm{ml}$ & + & + & + & + & + & + \\
\hline
\end{tabular}

Tabel 5. Hasil Pemeriksaan Uji Iritasi

\begin{tabular}{|ccccccc|}
\hline Keterangan & F1 & F2 & F3 & F4 & F5 & F6 \\
\hline Panelis I & - & - & - & - & - & - \\
Panelis II & - & - & - & - & - & - \\
Panelis III & - & - & - & - & - & - \\
Panelis IV & - & - & - & - & - & - \\
Panelis V & - & - & - & - & - \\
\hline
\end{tabular}

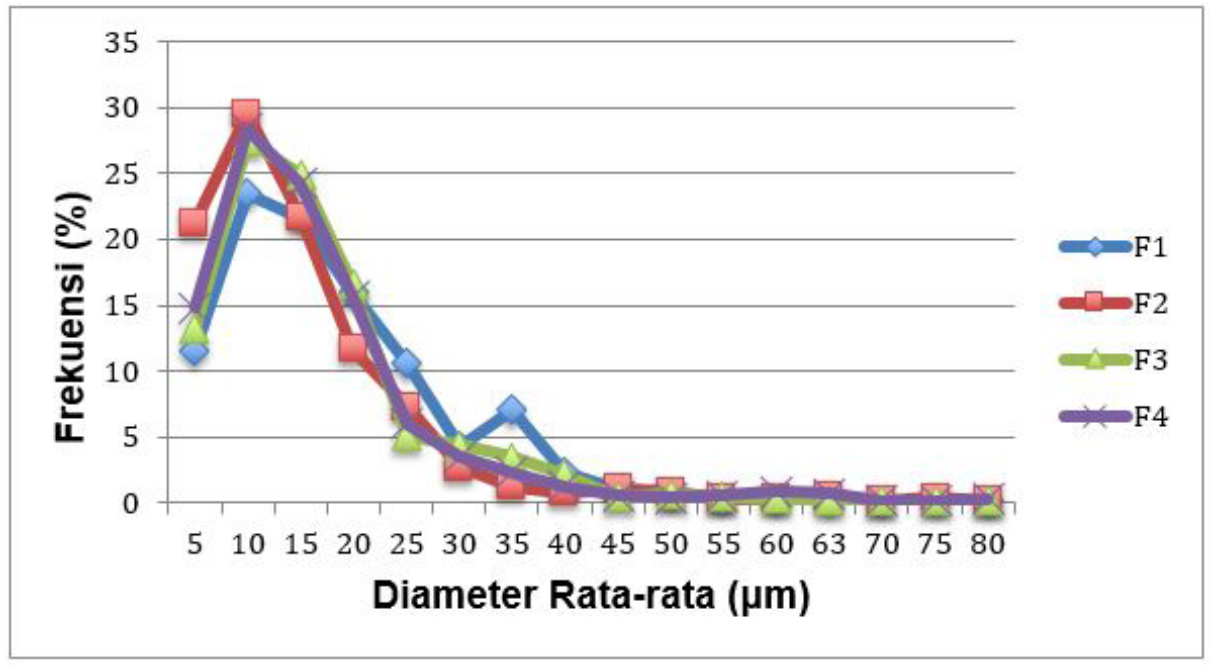

Gambar 1. Hasil Pemeriksaan Distribusi Ukuran Partikel 


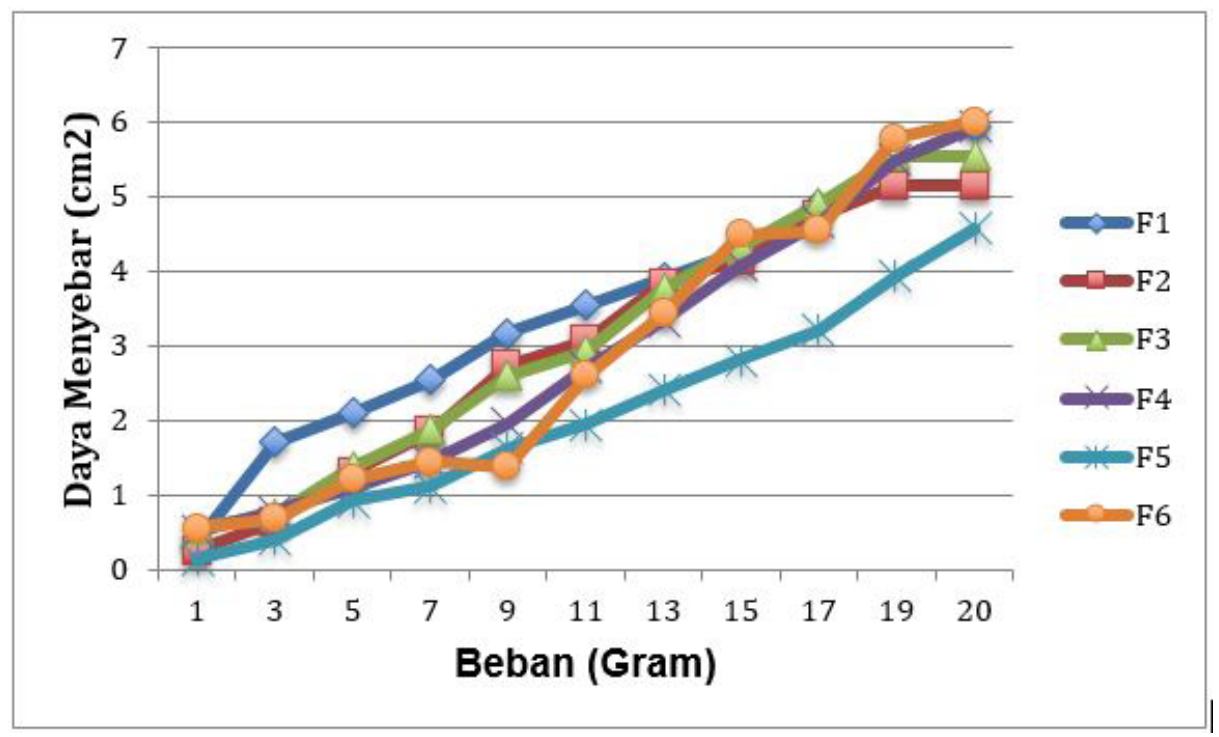

Gambar 2. Hasil Pemeriksaan Daya Menyebar

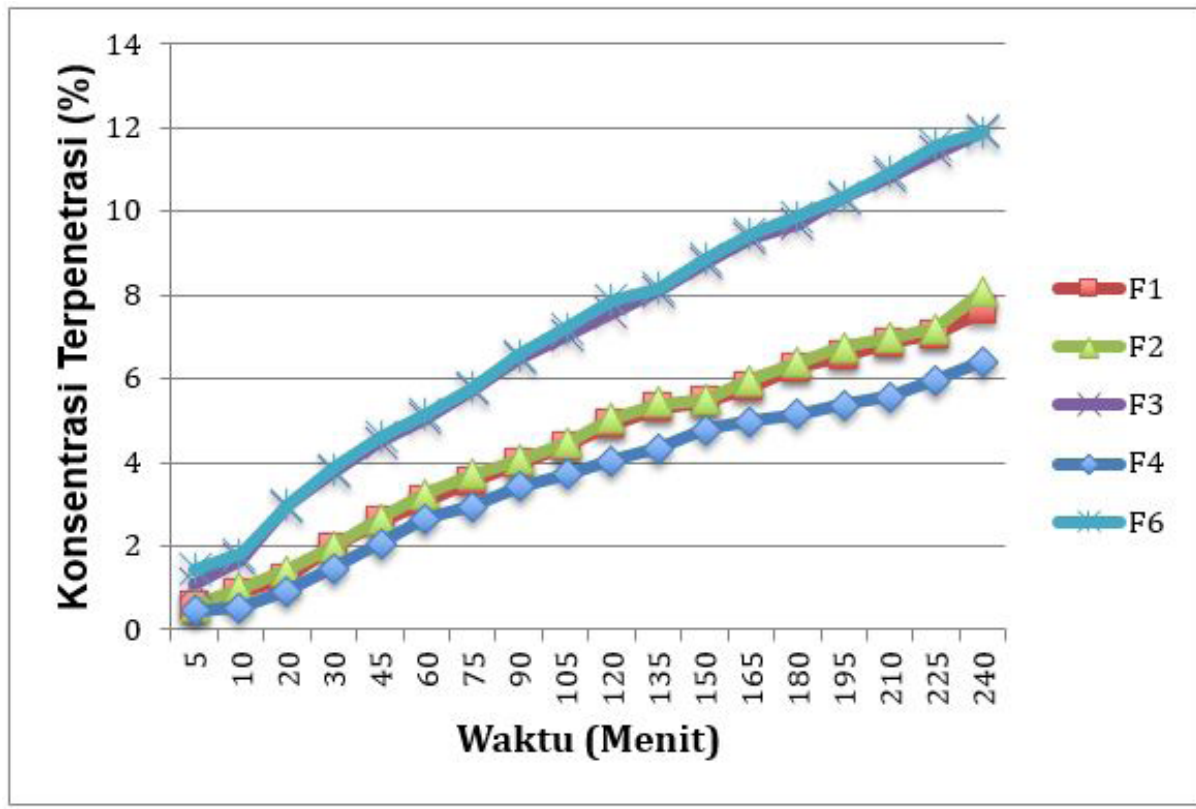

Gambar 3. Hasil Uji Penetrasi

\section{Kesimpulan}

Dari hasil penelitian yang telah dilakukan dapat diambil kesimpulan bahwa lama penggilingan asiklovir tidak mempengaruhi karakter dari sediaan cream. Proses penggilingan terhadap asiklovir menyebabkan terbentuknya agregrat sehingga terjadinya penurunan konsentrasi zat yang terpenetrasi. Semakin lama proses penggilingan asiklovir menyebabkan semakin rendahnya konsentrasi zat yang terpenetrasi.

\section{Ucapan Terimakasih}

Terimakasih kepada Fakultas Farmasi Universitas Andalas yang telah memberikan dana hibah penelitian BOPTN Fakultas Farmasi tahun 2018 yang membiayai penelitian ini. 


\section{Referensi}

[1] [Sweetman SC. Martindale: the complete drug reference. Edisi 36. London: Pharmaceutical Press; 2009

[2] Departemen Kesehatan Republik Indonesia. Farmakope Indonesia. Edisi IV. Jakarta : Depkes RI; 1995

[3] Hasler-Nguyen N, Shelton D, Ponard G, Bader M, Schaffrik M, Mallefet P. Evaluation of the in vitro skin permeation of antiviral drugs from penciclovir $1 \%$ cream and acyclovir $5 \%$ cream used to treat herpes simplex virus infection. BMC Dermatology 2009, 9:3 : 1-10

[4] Gold D, Corey L. Acyclovir Prophylaxis for Herpes Simplex Virus Infection. Antimicrob Agents Chemother 1987; 31:361-367.

[5] Spruance SL, Rea TL, Thoming C, Tucker R, Saltzman R, Boon R. Penciclovir Cream for the Treatment of Herpes Simplex Labialis. A Randomized, Multicenter, Double-Blind, Placebo- Controlled Trial. Topical Penciclovir Collaborative Study Group. JAMA 1997; 277:1374-1379.

[6] Visalli RJ, Courtney RJ, Meyers C. Infection and Replication of Herpes Simplex Virus Type 1 in an Organotypic Epithelial Culture System. Virology 1997, 230:236-243.

[7] Jarvis CA, McGuigan C, Heard CM. In Vitro Delivery of Novel, Highly Potent Anti-Varicella Zoster Virus Nucleoside Ana- logues to Their Target Site in the. Pharm Res 2004, 21(6):914-919.

[8] Magnoni F, Gigliobianco MR, Peregrina DV, Censi R, Di Martino P. Effect of grinding on the solid state stability and particle dissolution of acyclovir polymorphs. Journal of Pharmaceutical Sciences 2017.
[9] Lachman, L., H. A. Lieberman, \& J. L. Kang. The Theory \& Practice of Industrial Pharmacy 2nd Edition. Philadelphia: Lea \& Febringer. 1994.

[10] Jellinek JS. Formularium and Function of Cosmetic. London :Willey Interscience.1970.

[11] Voight R. Buku Pelajaran Teknologi Farmasi. Edisi 5. Diterjemahkan oleh Dr. Soendani Noerono. Yogyakarta: UGM Press; 1994.

[12] Noviza D, Afrianto D, Erizal, Halim A. The effect of milling process on acyclovir inclution complex with beta cyclodextrin. Journal of Chemical and Pharmaceutical Research, 2015, 7(12):354-362.

[13] Jacobs GA, Gerber M, Malan MM, du Preez JL, Fox LT, Plessis JD. Topical delivery of acyclovir and ketoconazole. Drug Deliv, 2016; 23(2): 631-641

[14] Spence JK, Bhattachar SN, Wesley JA, Babu SR Increased Dissolution Rate and Bioavailability Through Comicronization with Microcrystalline Cellulose. Pharmaceutical Development and Technology. 2005;10: 451-460.

[15] Agustin R, Sari N, Zaini E. Pelepasan Ibuprofen dari Gel Karbomer 940 Kokristal Ibuprofen-Nikotinamida. Jurnal Sains Farmasi \& Klinis. 2014;1(1): 79-88

[16] Shiow-Fern Ng, Rouse JJ, Sanderson FD, Meidan V, Eccleston GM. Validation of a Static Franz Diffusion Cell System for In Vitro Permeation Studies. AAPS PharmSciTech, 2010;11(3):1432-1441

Copyright $\odot 2018$ The author(s). You are free to share (copy and redistribute the material in any medium or format) and adapt (remix, transform, and build upon the material for any purpose, even commercially) under the following terms: Attribution - You must give appropriate credit, provide a link to the license, and indicate if changes were made. You may do so in any reasonable manner, but not in any way that suggests the licensor endorses you or your use, ShareAlke, - If you remix, 